\title{
Nutritional management and disease prevention in healthy dogs and cats
}

\author{
Andrea J. Fascetti ${ }^{1}$ \\ ${ }^{1}$ Department of Molecular Biosciences - School of Veterinary Medicine - University of California, Davis, CA, 95616-8741.
}

\begin{abstract}
Healthy animals normally eat sufficient food to satisfy their energy requirements. It is one of the jobs of the nutritionist to ensure that all other nutrient needs have been met when animals stop eating because they have met their energy needs. While dogs and cats are members of the biological order Carnivora, scientific observation and research support that differences in their metabolism and nutritional requirements exist. However, the goal in feeding both species is the same; to optimize the health and well-being of the individual. This approach results in dietary recommendations that will vary from individual animal to animal, based on a variety of factors that include the animal's signalment, occupation and environment. Feeding approaches vary between the two species and within the same species during different physiological life stages. However, the practice of feeding to maintain a lean body condition is a common goal. The maintenance of a lean body condition has been proven to increase both the quantity and quality of life in dogs. Currently, similar data does not exist in cats but is suspected to hold true. Each dog and cat's feeding program should be assessed routinely and adjustments made as indicated based on the animal's body condition, life stage and general health.
\end{abstract}

Key Words: canine, energy, feline, nutrition

\section{Manejo nutricional e prevenção de doenças em cães e gatos saudáveis}

\begin{abstract}
RESUMO - Animais saudáveis normalmente comem alimentos suficientes para satisfazer suas necessidades energéticas. Uma das funções dos nutricionistas é garantir que todas as necessidades de nutrientes ingeridas serão adequadas quando os animais pararem de comer após terem atingido suas necessidades energéticas. Enquanto cães e gatos são membros da ordem Carnivora, a observação científica e de pesquisa apoia as diferenças existentes em suas exigências nutricionais e o metabolismo. No entanto, o objetivo de alimentar as duas espécies é o mesmo, para otimizar a saúde e o bem-estar do indivíduo. Esta abordagem resulta em recomendações dietéticas que variam de animal para animal, com base em uma variedade de fatores que incluem a aparência do animal, sua atividade e o ambiente. Abordagens na alimentação variam entre as duas espécies e dentro da mesma espécie em diferentes fases da vida fisiológica. No entanto, a prática da alimentação para manter uma condição corporal magra é um objetivo comum. A manutenção de uma condição corporal magra tem sido comprovada para aumentar a quantidade e a qualidade de vida em cães. Atualmente, dados semelhantes não existem em gatos, mas provavelmente o mesmo deverá ocorrer. Cada programa de alimentação para cães e gatos deve ser avaliada rotineiramente e os ajustes, feitos conforme indicação com base na condição corporal do animal, no estágio de vida e na saúde em geral.
\end{abstract}

Palavras-chave: canino, energia, felino, nutrição

\section{Introduction}

Both dogs and cats are members of the biological order Carnivora. Scientific observation and research support that differences in their metabolism and nutritional requirements exist. The differences in nutritional requirements likely correlate with the evolution of these two species. Nutritionally and metabolically, dogs and other members of Cannidea are generally considered omnivores, whereas cats and other members of the family Felidea are regarded as carnivores. However, there exist nutritional and metabolic examples that are not consistent with the view that the cat is a strict carnivore and the dog is simply an omnivore.
The only member of the family Felidea whose nutritional requirements have been studied extensively is the domestic cat (Felis catus). Scientific research has shown that cats have obligatory requirements for nutrients that are not essential for many other mammals. The high protein requirement of cats is due to their high requirement for nitrogen. This appears to be because cats have a limited ability to control the activity of their aminotransferases and urea cycle enzymes (Rogers et al., 1977; Green et al., 2008). Conversely, cats are able to control the activity of enzymes in the first irreversible step of essential amino acid degradation to some extent; explaining why they do not have a high requirement for essential amino acids 
(Rogers \& Morris, 1980). The lack of down-regulatory control over aminotransferases and urea cycle enzymes renders cats immediately able to metabolize and use amino acids for gluconeogenesis and as an energy source. Additional benefits of this ability are realized in times of starvation; carnivores are better able to immediately maintain blood glucose concentrations compared to omnivorous species (Morris, 2002).

There are five other nutrients, considered essential in feline diets that are not recognized as essential in most other species due to the low activities of enzymes in their synthetic pathways. Two of these nutrients are the amino acids arginine and taurine. The low activities of ornithine aminotransferase and pyrroline-5-carboxylate result in the minimal production of citrulline in the gastrointestinal tract (Costello et al., 1980; Rogers \& Phang, 1985). As a result, the cat is completely dependent upon dietary arginine to meet its needs for this amino acid. The endogenous synthesis of taurine is limited by the low activities of cysteine dioxygenase and cysteinesulphinic acid decarboxylase

(Park et al., 1999). The low activity of these enzymes in the synthetic pathway, coupled with the low affinity of $\mathrm{N}$ acyltransferase for glycine for bile acid synthesis, results in the depletion of body taurine stores. The remaining three nutrients are niacin and vitamins $\mathrm{A}$ and $\mathrm{D}$. The cat has a dietary requirement for niacin and vitamin $\mathrm{D}$ because of the high activity of the enzymes picolinic carboxylase (Sudadolnik et al., 1957; Ikeda et al., 1965) and 7-dehydrocholesterol- $\Delta^{7}$ - reductase (Morris, 1999), respectively, that result in the degradation of precursors for their synthesis. Vitamin A must be supplied pre-formed in the diet presumably because cats lack or have reduced activity of the enzyme $\beta, \beta$-carotene 15,15 '-dioxygenase, needed to cleave $\beta$-carotene (NRC, 2006).

Consistent with their classification as obligate carnivores, cats have a reduced number of carbohydrate metabolizing enzymes compared to omnivores. Cats lack glucokinase in their livers (Washizu et al., 1999). However in contrast to certain others carnivores, and not at all consistent with the cat being a strict carnivore, cats can efficiently digest cooked starch (Morris et al., 1977; Kienzle, 1993).

Nutritionally and metabolically many consider the dog an omnivore. However there are nutritional and metabolic characteristics that dogs share with the cat. One veterinary nutritionist (personal communication, D. Kronfeld) has suggested the term "adaptive carnivore" when referring to the dog. In contrast to the cat, and similar to other omnivores, the dog has the ability to make taurine from the sulfur amino acid precursors methionine and cysteine
(Hayes, 1988), as well as vitamin A from $\beta$-carotene (Turner, 1934). However, unlike many other omnivores and more like the cat, the dog conjugates bile acids only with taurine (Haslewood 1964) and cannot make vitamin D, an animal product (Hazewinkel et al., 1987; How et al., 1994; NRC, 2006). Like cats, dogs require a source of dietary arginine to maintain nitrogen balance in adults and puppies (Ha et al., 1978; Czarnecki \& Baker, 1984). The dog's requirement for arginine is less than that of the cat but greater than the rat (NRC, 2006), positioning it between carnivores and other omnivores nutritionally.

Over time, evolution rendered some of the metabolic pathways and enzymes present in omnivores redundant in the cat. These pressures likely resulted in changes in biochemical pathways and nutritional requirements more suited to the cat's metabolism (Morris, 2002). Although nutritional requirements of the cat differ from that of the dog, scientific findings and observations are not fully consistent with the cat being a strict carnivore and the dog a simple omnivore.

\section{Feeding the healthy dog and cat}

Unlike the feeding approach to production animals, dogs and cats are evaluated and fed on an individual basis. The ultimate goal is to optimize the health and well-being of the individual. This approach results in dietary recommendations that will vary from animal to animal, based on a variety of factors that include the animal's signalment, occupation and environment.

Healthy animals normally eat sufficient food to satisfy their energy requirements. It is one of the jobs of the nutritionist to ensure that all other nutrient needs have been met when animals stop eating because they have met their energy needs. The greatest metabolic demands occur during growth, gestation and lactation, and this is when a marginal diet is most likely to result in nutritional problems. The majority of commercial pet foods are formulated to ensure adequate intake of all required nutrients based on energy intake as long as consideration is given to the manufacturer's life-stage recommendation.

How much to feed

Before recommending an amount to feed, the animal should undergo a routine physical examination to ensure that it is healthy. In addition to a physical examination, the animal's body weight and body condition score (BCS) should be noted, as this information is critical in determining your ultimate feeding recommendations. A BCS is a subjective assessment of body composition that has been validated to correlate with more a quantitative measure of body condition, dual energy X-ray 
absorptiometry (Laflamme et al., 1994). Several BCS systems have been proposed using 3,5 , or 9 points. The preferred system is different from person to person. The five point system scored to the nearest $1 / 2$ unit is equivalent in discriminating capability to a nine point system scored to the whole unit. When using the 5 -point system, a 3 out of 5 is considered ideal. Each point on the 5 point scale represents an increase or decrease of $20-30 \%$ in body fat above or below ideal (i.e. 1 very thin and 5 obese). A 4 or 5 out of 9 is considered ideal when using the 9 point system. Each subsequent point on the 9-point scale represents an increase or decrease of 10-15\% in body fat above or below ideal (i.e. 1 emaciated and 9 grossly obese). More important than the system that you chose, is the selection of a system that is used consistently on every patient.

Ideally the amount of food to feed an animal should be determined by coupling the information from the exam, body weight and body condition score with a diet history. An example of a diet history form can be found at the University of California, School of Veterinary Medicine, Nutrition Support Service's web site: (http:// www.vetmed.ucdavis.edu/vmth/small_animal/nutrition/ newsletters.cfm). Diet history forms should be obtained and updated for every patient routinely. Information that should be included in every diet history form includes, the specific product name, form (i.e., dry, canned or semi-moist) and manufacturer of the pet's diet, quantitative data on how much the pet is consuming daily, details regarding names and amounts of snacks and treats, information about who feeds the pet and the setting in which the pet consumes its food. In instances where owners are home-preparing the pet's meals, detailed information on the ingredients and supplements as well as preparation methods should be recorded. When the animal is in an ideal body condition, weight stable, and otherwise healthy, this author recommends feeding the amount of food the animal is currently consuming provided an accurate and detailed diet history is available.

Determining the amount of calories to feed becomes more difficult if a diet history is unavailable. Many pet foods provide guidelines on the product label and these can be used as a starting point. However, it is important to understand that these guidelines are limited. Controlled studies have demonstrated that energy requirements may vary significantly among similar animals housed in similar conditions (NRC, 2006).

If it is necessary to calculate the animal's energy requirements, the author recommends determining the animal's maintenance energy requirement (MER) by using the resting energy requirement (RER) equation and then multiplying by the factor for the appropriate life stage (Thatcher et al. 2010) rather than using the single MER equation. In this author's experience this approach is more conservative and tends to less frequently overestimate the true energy needs of the animal. To calculate resting energy expenditure use an exponential equation $(70 \mathrm{x} \mathrm{kg}$ $\left.\mathrm{BW}^{0.75}\right)=(\mathrm{kcal} / \mathrm{g})$ or a linear equation $70+(30 \mathrm{x} \mathrm{kg} \mathrm{BW})$ $=(\mathrm{kcal} / \mathrm{g})($ Thatcher et al., 2010). Maintenance energy requirements are then multiplied by a factor which takes into account the age and the physiological condition of the animal. The following factors have been suggested for cats (obese prone adult $=1.0$, neutered adult $=1.2$, intact adult $=1.4$, active adult $=1.6$ ) and dogs (obese prone $=1.4$, neutered adult $=1.6$, intact adult $=1.8$, light work $=2$, moderate work $=3$, heavy work $=4-8$ ) $($ Thatcher et al., 2010). This approach allows flexibility with which factor is used to determine the energy needs. However it must be stated that it is unclear in many cases how these factors were derived and they have not been tested to determine if they are more accurate than any other approach.

An alternative approach is to use the equation specifically derived to determine MER (NRC, 2006). The NRC (2006) recommends the following equation to predict MER for kenneled or active pet dogs; $130 \mathrm{~kg} \mathrm{BW}^{0.75}=\mathrm{kcal} /$ day. Instead of using 130 in the previous equation, the NRC then recommends multipliers for dog groups with lower or higher energy requirements. The multipliers for various groups include; inactive dogs $=95$, older active dogs $=105$, Newfoundlands $=105$, young, active dogs $=140$, active terrier breeds $=180$ and active Great Danes $=200$ (NRC 2006). The NRC-recommended equations for cats are the following: lean cats (cats with a body condition score of less than or equal to 5 on a 9 point scale), $100 \mathrm{~kg} \mathrm{BW}^{0.67}=$ $\mathrm{kcal} /$ day, overweight cats (cats with a body condition score of greater than or equal to 6 on a 9 point scale), $130 \mathrm{~kg}$ $\mathrm{BW}^{0.40}=\mathrm{kcal} / \mathrm{day}$. In many cases the single MER equation overestimates the animal's energy needs (Lewis et al., 1987a). However, it is imperative to remember that the calculated amount to feed is only an educated guess and that this amount may vary by as much as $50 \%$, particularly for dogs (NRC, 2006). The animal's weight and body condition score should be monitored frequently and the caloric intake adjusted accordingly.

\section{How to feed}

There are basically three types of feeding regimens that an owner can use to feed their dog or cat. These include free choice feeding (ad libitum or self feeding), time-restricted feeding and portion-controlled feeding (meal feeding). It is 
also not uncommon to see more than one of these used in the same animal.

Ad libitum feeding ensures that there is a surplus of food available at all times and relies upon the animal regulating their daily caloric intake. This type of feeding allows cats to consume small multiple meals throughout the day, closely mimicking their natural feeding behavior (Kane et al., 1981). This method of feeding provides the least amount of work on behalf of the owner, ensures that subordinate animals in multiple pet households have the opportunity to eat and helps to minimize the noise associated with feeding and may relieve boredom in kenneled animals. Furthermore there may be an advantage concerning energy balance due to meal-induced energy loss. The disadvantages associated with an ad libitum feeding schedule include the likelihood of overlooking medical problems, anorexia and the denial of food to subordinate animals. It has been suggested that $30-40 \%$ of dogs and cats will overeat if food is available at all times (NRC 2006), so this style of feeding increases the probability that an animal will become overweight. Dry food is the only type of pet food that can be fed in this manner.

Similar to ad libitum feeding, time-restricted feeding relies upon the animal's ability to regulate their daily caloric intake. At meal time a surplus of food is given, and the pet is allowed to eat for a set period of time. This form of feeding is most applicable to dogs and not practical for cats. The major advantages of this method are that it does not require much effort on behalf of the owner, may be used with any type of pet food and permits some monitoring of the dog's food intake. This form of feeding may be inappropriate for fastidious animals and may encourage gluttony and aerophagia.

With portion-controlled feeding the dog or cat is given a specific amount of food, often divided into two meals per day. This method of feeding is considered by many experts to be the best approach for both dogs and cats in all life stages with the exception of geatation/lactation. This method allows the owner to carefully monitor their pet's food intake, lowers the probability of obesity and alerts an owner much sooner to any medical problems or anorexia. The biggest disadvantage is that it requires more of an effort on behalf of the owner.

Offering a treat or sharing food with one's pet is an important part of the human-animal bond and should be included in a diet plan for every patient. Intake from snacks or treats should not exceed $10 \%$ of the animal's total daily calories or one risks unbalancing a balanced diet. The
United States Department of Agriculture's (USDA) National Nutrient Database for Standard Reference (http:// www.nal.usda.gov/fnic/foodcomp/search/) is a useful resource to determine the calorie content of human foods if used as treats.

\section{What to feed}

One question the author is often asked is, "What is the best diet for my pet?". The answer is "There is not one diet that is best for every cat or dog. Cats and dogs are individuals, and the best diet will vary from animal to animal." That being said, it is helpful to clients to provide some guidelines for choosing a diet for their healthy animal and even more helpful if one can give them a few specific recommendations. When considering the appropriate response to this question, it is important to consider three factors; the animal in question, the variety of external factors that may influence how and what the animal is fed and then finally the product itself.

There are many factors related to the animal that will influence your suggestions. One must consider not only the animal's signalment (i.e., age, species, breed and sexual status) but its body condition, activity levels and food or texture preferences. External factors can have a strong influence on your final dietary recommendations for the pet. Knowing the owner's budget can help narrow your recommendations to products that meet their price range. The diet and how the animal is fed may be influenced by its environment which includes, but is not limited to, the number and type of the animals in the household, where the animal is housed (i.e., indoors versus outdoors), the human inhabitants of the house (i.e., a household with small children, elderly individuals or adults only), and the feeding philosophies of the owner.

After assessing your patient and reviewing the other factors in that animal's environment, consideration needs to be given to the product itself. It is important to select a diet that supports the life stage of the patient that one is feeding and a lean body condition when fed at an appropriate amount. The author recommends feeding foods produced by larger manufacturers, so that if there is a problem with a particular diet it will likely be detected sooner. Strong consideration should be given to companies that employ animal nutritionists and support research in an effort to continually improve foods and the knowledge about dog and cat nutrition. When making specific recommendations, the author prefers foods that have undergone and passed feeding trials in accordance with the Association of American Feed Control Officials’ (AAFCO) guidelines (2009). 
Feeding guidelines for different life stages

\section{Gestation and lactation}

For mammals, the period of pregnancy puts a significant nutritional demand on both the dam and the fetus. Given the nutritional demands of this life-stage, it is important that the diet be one that supplies all the energy and nutrients needed to meet the maintenance requirements of the queen or bitch in addition to supplying all the energy and nutrients required to support fetal growth and development and milk demands during lactation (Wills, 1996).

Cats and dogs should be fed a complete and balanced diet formulated for gestation and lactation and be in an ideal body condition prior to breeding. Animals that are significantly under- or overweight should not be bred until their body condition is closer to ideal. Malnourished queens are more likely to not conceive or have kittens that are underweight and perform poorly during lactation (personal communication, A.J. Fascetti). Puppies born to malnourished dogs have reduced birth weights, are prone to hypoglycemia, and have poor survival rates (Schroeder et al., 1994). Obese cats have a higher incidence of dystocia (Lawler \& Monti 1984) and bitches that are obese prior to breeding have lower ovulation rates, smaller litter sizes and perform poorly during lactation (Bebiak et al., 1987; Debraekeleer et al., 2010).

Weight gain in cats is unlike other mammals such as humans and dogs, where most weight is gained in late pregnancy (Wills, 1996). Cats, like pigs, show a different pattern characterized by a linear gain throughout pregnancy that is independent of the number of fetuses (Loveridge, 1986; Wichert et al., 2009). Energy intake parallels this linear weight gain. It has been estimated that energy requirements increase approximately 25-50\% above maintenance to between $90-100 \mathrm{kcal} / \mathrm{kg}$ body weight/day (Loveridge \& Rivers, 1989). Unlike cats, the bitch's energy requirements will not increase until the last third of gestation. In general the average bitch will gain anywhere from 15-25\% of her pre-breeding weight prior to whelping (Burger, 1993). Energy requirements in dogs for gestation peak anywhere between $30-60 \%$ of the pre-breeding requirements depending upon the litter size (Romsos et al., 1981; Debraekeleer et al., 2010). Just prior to and immediately following parturition cats, food intake is reduced, but quickly increases driven by the need for energy to meet the demands of lactation (Burger, 1993). It was historically thought that queens return to their prebreeding weight at weaning (Loveridge \& Rivers, 1989), however, a recent study found that most queens were heavier than their breeding weight two weeks following weaning (Wichert et al., 2009). The retention of some weight allows the queen to maintain a body fat reserve to use as energy during lactation (Wills, 1996). In dogs, energy requirements continue to increase following whelping and into lactation, peaking at approximately 3-5 weeks. At this point, energy requirements can fall between 2-4 times the adult maintenance requirement (Ontko \& Phillips, 1958; Burger, 1993).

A diet designed to support the life stages of gestation and lactation should be started prior to breeding and fed to maintain an ideal body condition. To further assist with this goal, queens should be fed free choice throughout these two life stages. Since the need for extra energy and nutrients is relatively small initially for dogs, a gradual increase in amount of energy offered can be started during the second half of gestation. Every dog should be fed on an individual basis, but one suggestion is to consider beginning to increase the amount of calories offered by 10 $15 \%$ each week around the fifth week of gestation until whelping (Wills, 1996). This approach results in an overall increase of approximately 40-60\% compared to the food intake of the bitch at the time of breeding. Ad libitum feeding is recommended in dogs during lactation. Following weaning of the offspring, both queens and bitches can be returned to their normal maintenance ration.

Some breeders regularly supplement their bitch's or queen's diet with calcium or calcium-containing foods such as cottage cheese, throughout gestation or lactation. This stems from the theory that the added minerals will ensure healthy fetal development, prevent eclampsia and aid in milk production. This practice is not necessary as long as the dam is consuming a commercial ration designed to support gestation/lactation. In fact, some experts feel that excess supplements during pregnancy may adversely affect skeletal development, result in fetal deformities or problems during growth, and actually increase the likelihood of eclampsia (Linde-Forsberg, 2010).

Assessment of the suitability of the feeding plan for the queen or bitch should be conducted routinely and is done primarily by observation and determination of the health and body condition score of the dam. Poor or inadequate milk production during lactation may also be reflected in high neonatal mortality rates, poor growth rates and continuous vocalization indicating hunger in the offspring. If the body condition of the dam drops below 4-5/9, consideration should be given to adjusting the amount or type of food offered (preferably more energy dense and/or more palatable) after other causes of weight loss have been eliminated. 


\section{Growing cats and dogs}

Kittens normally weigh 90-110 g at birth and should gain 50-100 g until 5-6 months of age (Willis \& Morris, 1996). Puppies should gain 2-4 g/day/kg of anticipated adult weight for the first 5 months of life (Lewis et al., 1987b). If the dog should weigh $20 \mathrm{~kg}$ as an adult, the puppy should gain 40-80 g/day. Excessive feeding during growth can lead to obesity and in large breed dogs can result in skeletal problems (Hedhammer et al., 1974; Lavelle, 1989; Kealy et al., 1992). Studies have demonstrated that controlled, meal feeding of pups leads to a slower growth rate, less skeletal problems, but does not decrease the final mature body size compared to pups fed free choice (Hedhammer et al., 1974). In kittens, excessive growth rates do not invoke the same consequences as in dogs; however, obesity can become a problem. Often kittens are fed free choice so monitoring is essential to catch and eliminate any excessive weight gain. At weaning, every growing animal should be fed a complete and balanced diet designed, and preferably tested, for growth or all life stages.

Multiple studies have shown that intact adult pets generally weigh less than neutered animals of the same breed and size (Root, 1995; Duch et al., 1978; Houpt et al., 1979; Flynn et al., 1996; Fettman et al., 1997). This is probably a combination of physiological and environmental factors. Owners are generally encouraged to neuter their pets between 6 months and 1 year of age. This time period corresponds to a natural decrease in the animal's growth rate and energy needs. If owners are not aware of this change, and continue to feed their pet the same amount of food, excess weight gain will result. Increasing age and a change in sexual status are also associated with a decrease in voluntary physical activity. Recent studies have demonstrated that ovariohysterectomy and castration in cats leads to an increase in food intake and weight gain (Fettman et al., 1997; Martin et al., 2001; Kanchuk et al., 2003; Nguyen et al., 2004).

There are several steps that an owner can take to prevent weight gain in their pet following neutering. Changing from an ad libitum feeding approach to one in which the food is offered in carefully controlled meals may prevent weight gain. Alternatively, one can consider feeding a diet with a lower energy density.

It is important to monitor kittens and puppies frequently during the growth process. This monitoring is facilitated by the fact that they are visiting the veterinary office frequently during this life stage for check-ups and vaccinations. Puppies and kittens should be weighed and body condition scored at every visit and the diet history form updated. If there is excessive weight gain or a body condition score greater than $5 / 9$, owners should be directed to feed $10 \%$ less calories (or more if indicated based on the animal's weight, body condition and calorie intake). Alternatively, if the animal is not growing normally or is underweight, and metabolic causes have been eliminated, consideration should be given to increasing the amount of food fed by $10 \%$. Regardless of the problem, the animal should come back for a weight and body condition score check within 2-3 weeks to ensure that they are returning to an ideal body condition and growing normally.

\section{Adult cats and dogs}

In addition to feeding a diet that is nutritionally formulated to meet the nutrient needs of dogs and cats, probably the most important feeding recommendation for this life stage is to keep animals in a lean body condition. The maintenance of a lean body condition has been proven to increase both the quantity and quality of life in dogs (Kealy et al., 2002). Currently there is no similar data in cats. Obesity has been linked to diabetes mellitus, lameness and skin disease (Scarlett \& Donoghue, 1998) and is a risk factor for hepatic lipidosis in anorexic cats (Biourge et al., 1994). One might surmise that by avoiding conditions that contribute to early mortality by maintenance of a lean body condition, one will secondarily contribute to life extension in cats as well.

There exists some controversy regarding whether it is better to feed cats dry compared to canned diets. Proponents of canned food cite the documented increase in water consumption in cats consuming such products (Kane, 1981), the possible prevention of urinary tract problems, and the potential voluntary reduction in calories helping to prevent weight gain in cats. Proponents of dry food cite the dental health benefits, the ability to feed ad-libitum thereby more appropriately mimicking the natural pattern of food intake in the cat (Kane, 1981), and the esoteric pleasure of consuming food that is crunchy and requires chewing. Consideration should be given to these variables and the animal's preferences when recommending one type of food over another. However, the author recommends exposing young cats to the different food formats to prevent texture preferences that might otherwise limit future diet options.

Success of the feeding program can be evaluated based on the animal's maintenance of a lean body condition and an active life style. A diet history should be updated at every visit to maintain historical records on the types and amount of calories fed, in case conditions requiring dietary modification occur in the future. Frequent alterations in the diet or a significant increase or decrease in food intake may be an early indicator of an underlying problem. 


\section{Senior cats and dogs}

Although the concept of aging is difficult to define, most experts agree that aging is not a disease. It is difficult to define old age in dogs and cats. The aging process varies tremendously from individual to individual and is influenced by an animal's breed, size, genetics, nutrition, environment and other factors. As a general rule, larger dog breeds have a shorter life expectancy than smaller breeds and mixedbreed dogs live longer than purebreds of a similar size.

In many dogs, resting and maintenance energy requirements decrease as they age (Kienzle \& Rainbird, 1991; Speakman et al., 2003). Multiple studies examining a variety of breeds estimated an $18-24 \%$ reduction in maintenance energy requirements compared to those of younger dogs (Finke, 1991; Kienzle \& Rainbird, 1991; Taylor et al., 1995; Harper, 1997). The change in energy requirements is also related to changes in body composition. It has been reported that there is a highly significant, negative linear correlation between age and lean:fat ratios in dogs (Meyer \& Stadtfeld, 1980; Harper, 1998b).

The situation appears to be somewhat different in cats, previous evidence suggested that maintenance energy requirements remained constant throughout adult life (Anantharaman-Barr et al., 1991; Taylor et al., 1995; Harper, 1998a). These findings were supported by additional work that did not document a change in the lean:fat ratio in cats with age (Munday \& Earle, 1994; Harper, 1998b). However, more recent studies suggest that maintenance energy requirements decrease in mature cats compared to younger cats but increase again when the cats became older at approximately 10-12 years of age (Cupp et al., 2004; Perez-Camargo, 2004; Laflamme, 2005).

Age related changes in digestiv e physiology, hormones and gut microbiata may directly or indirectly reduce digestive capacity (Fahey et al., 2008). On histological examination, changes are evident in the salivary glands, small intestine, liver and pancreas of older dogs (Mundt, 1991), however these changes do not reduce apparent nutrient digestibility in dogs (Lloyd \& McCay, 1954; Lloyd \& McCay, 1955; Sheffy et al., 1985; Buffington et al., 1989; Taylor et al., 1995). Several studies have reported reductions in the digestibility of protein, fat and starch in older cats (Taylor et al., 1995; Peachey et al., 1999; Patil \& Cupp, 2010).

The aging process results in a general reduction in the sensations of vision, hearing, taste and smell (Markham \& Hodgkins, 1989). Alterations in the immune system associated with age are well recognized (Day, 2010). Behavioral changes are common in older pets and are a frequently overlooked physiological alteration that may affect the animal's ability, or desire to obtain adequate nutrition. Behavioral changes can be the result of many disorders including systemic illness, organic brain disease, true behavioral problems or cognitive dysfunction syndrome (CDS) (Nielson et al., 2001; Gunn-Moore et al., 2007).

Elderly pets have the same nutrient needs as their younger counterparts (NRC, 2006). However, the quantities per unit of body weight may change, and the way they are provided may require modification. Feeding recommendations for this life stage are not unlike any other life stage in that each animal should be treated as an individual and as a consequence will vary from patient to patient.

If an animal's energy needs decrease without a reduction in caloric intake, obesity will develop. Some diets for mature dogs and cats are designed with higher fiber levels to combat this problem by decreasing the food's energy density. However, not all animals will gain weight as they age, many remain weight stable and a large number will experience varying degrees of weight loss. This latter population of pets may benefit from more energy dense, palatable diets to help them maintain, or gain weight. Similar to other life stages, dogs and cats should be fed to maintain a lean body condition through their senior years.

The decline in lean body mass that occurs with aging results in a loss of protein "reserves" in the body needed to combat stress and disease. Results from one study found that older dogs required up to $50 \%$ more protein than young dogs, to maintain labile protein (Wannemacher \& McCoy, 1966). A more recent study fed 8 year old Pointers either 16.5 or $45 \%$ protein calories over a 2 year period and reported a reduction in lean body mass in both groups (Kealy, 1999). Hannah \& Laflamme (1996) reported maintenance of lean body mass in adult cats consuming $36 \%$ protein on a dry matter (DM) basis. Cats consuming lower amounts of protein (22 and 28\% DM) maintained nitrogen balance but lost lean body mass.

The quality of protein is an important consideration. To reduce bacterial metabolites, the protein should have a high biological value and a high pre-cecal digestibility. Most commercial pet foods are formulated to exceed minimum requirements, so adequate protein is usually not a concern. However, if energy intake is reduced secondary to a decreased metabolic rate, or food intake, the protein to calorie ratio may need to be adjusted to meet the protein requirement. Furthermore, some high-energy foods with reduced protein concentrations, such as products designed 
to address renal or liver failure, do not provide as high a level of protein, especially if food intake is reduced.

There is a great deal of controversy concerning the restriction of protein in elderly animals as a measure to prevent renal disease. Although there is evidence that protein restriction is effective in minimizing the clinical signs of renal failure once disease is present (Elliott et al., 2000; Jacob et al., 2002), there is no evidence that protein restriction is of any benefit to healthy older dogs and cats. Considering that older dogs may have an increased protein requirement, that there is loss of lean body mass in both dogs and cats with advancing age, and that a decline in protein digestibility exists in older cats, the author does not recommend protein restriction in older dogs and cats unless indicated by an underlying disease.

Recently, there has been an advent of diets on the market enhanced with antioxidants to support immune function. The implication is that such enhancement will extend, or reverse the aging process and prevent or reduce the likelihood of disease. Documented alterations in immune and antioxidant parameters in dogs and cats (Hayek et al., 2000; Kearns et al., 2000; Massimino et al., 2003) as well as clinical improvement in cognitive function in dogs through supplementation has been reported (Head, 2007). Existing studies do not address the possible preventive or long-term effects of these supplements and diets, and if animals consuming them will live longer or have a lower incidence of disease.

The major objectives of a feeding program designed for an older pet should include the maintenance of health and an optimal body weight, the slowing or prevention of chronic disease, and the improvement of clinical signs of diseases that may already be present. Elderly dogs or cats that are healthy, in a lean body condition and eating an appropriate diet do not need to be changed to another diet simply based of their age. Owners should be instructed to monitor their animal's food intake, as alterations may indicate the presence of an underlying disease process. Proper care of the pet's teeth and gums is essential to prevent a reduction in food intake secondary to dental problems. Based on the animal's physical condition, regular and sustained periods of exercise should be recommended for all patients. Regular exercise helps maintain muscle tone, optimal body weight and enhances circulation.

In contrast to obese animals, some geriatric dogs and cats may have the problem of unintended weight loss and this may often be overlooked. This weight loss may be associated with an increase or decrease in food intake. If the animal is consuming more food secondary to a recent change to a food with a lower caloric density, this response could be normal. Less energy dense pet foods may be inappropriate for an animal with unusually high energy needs or an active life style. Alternatively, an underlying metabolic process may be present. If a specific cause for unintended weight loss cannot be determined, symptomatic treatment for weight loss should be instituted. Feeding an energy-dense, nutrient-dense, highly palatable food more frequently would be appropriate. Examples include, but are not limited to, diets designed for growth, critical care formulas or offering cat food to dogs.

Recently experts have been recommending that an appointment for an elderly pet include blood, fecal and urine analyses on a routine basis (Fortney, 2010). Although many of these tests are not sensitive indicators of nutritional status, they may indicate the presence of a subclinical process that may be nutrient responsive.

\section{References}

ANANTHARAMAN-BARR, H.G.; GICQUELLO, P.; RABOT, P. The effect of age on digestibility of macronutrients and energy in the cat. Proceedings of the British Small Animal Veterinary Association, p.164 (abstract), 1991.

BIOURGE, V.C.; GROFF, J.M.; MUNN, R.J. et al. Experimental induction of hepatic lipidosis in cats. American Journal of Veterinary Research, v.55, p.1291-1302, 1994.

BUFFINGTON, C.A.; BRANAM, J.E.; DUNN, G.C. Lack of effect of age on digestibility of protein, fat and dry matter in Beagle dogs. In: BURGER, I.H.; RIVERS, J.P.W. (Eds.) Nutrition of the dog and cat. Cambridge: Cambridge University Press, 1989. 397p.

BURGER, I.M. The Waltham book of companion animal nutrition. Oxford: Pergamon Press, 1993.

COSTELLO, M.J.; MORRIS, J.G.; ROGERS, Q.R. Effect of dietary arginine level on urinary orotate and citrate excretion in growing kittens. Journal of Nutrition, v.110, p.1204-1208, 1980 .

CUPP, C.; PEREZ-CAMARGO, G.; PATIL, A. et al. Long-term food consumption and body weight changes in a controlled population of geriatric cats. Compendium on Continuing Education for the Practicing Veterinarian, v.26, p.60, 2004. (suppl 2A)

CZARNECKI, G.L.; BAKER, D.H. Urea cycle function in the dog with emphasis on the role of arginine. Journal of Nutrition, v.114, p.581-590, 1984.

DAY, M.J. Ageing, immunosenescence and inflammageing in the dog and cat. Journal of Comparative Pathology, v.142, p.S60-69, 2010 (Suppl. 1).

DEBRAEKELEER, J.; GROSS, K.L.; ZICKER, S.C. Feeding reproducing dogs. In: HAND, M.S.; THATCHER, C.D.; REMILLARD, R.L. et al. (Eds.). Small animal clinical nutrition. Topeka: Mark Morris Institute, 2010. p.281-294.

DUCH, D.S.; CHOW, F.H.C.; HAMAR, D.W. et al. The effect of castration and body weight on the occurrence of the feline urological syndrome. Feline Practice, v.8, p.35-40, 1978.

ELLIOTT, J.; RAWLINGS, J.M.; MARKWELL, P.J. et al. Survival of cats with naturally occurring chronic renal failure: effect of dietary management. Journal of Small Animal Practice, v.41, p.235-242, 2000.

FAHEY, G.C.; BARRY, K.A.; SWANSON, K.S. Age-related changes in nutrient utilization by companion animals. Annual Reviews of Nutrition, v.28, p.424-445, 2008. 
FETTMAN, M.J.; STANTON, C.A.; BANKS, L.L. et al. Effects of neutering on body weight, metabolic rate and glucose tolerance of domestic cats. Research in Veterinary Science, v.62, p.131-136, 1997.

FINKE, M.D. Evaluation of the energy requirements of adult kennel dogs. Journal of Nutrition, v.121, p.S22-S28, 1991.

FLYNN, M.F.; HARDIE, E.M.; ARMSTRONG, P.J. Effect of ovariohysterectomy on maintenance energy requirement of cats. Journal of the American Veterinary Medical Association, v.209, p.1572-1581, 1996.

FORTNEY, W.D. Declining physiological reserves: defining aging. In: COMPANION ANIMAL NUTRITION SUMMIT, FOCUS ON GERONTOLOGY, 2010, Clearwater Beach, Florida. Proceedings... Clearwater Beach, 2010. p.1-6.

GREEN, A.S.; RAMSEY, J.J.; VILLAVERDE, C. et al. Cats are able to adapt protein oxidation to protein intake provided their requirement for dietary protein is met. Journal of Nutrition v.138, n.6, p.1053-1060, 2008.

GUNN-MOORE, D.A.; MOFFAT, K.; CHRISTIE, L.A. et al. Cognitive dysfunction and neurobiology of aging cats. Journal of Small Animal Practice, v.48, p.456-553, 2007.

HA, H.Y.; MILNER, J.A.; CORBIN, J.E. Arginine requirements in immature dogs. Journal of Nutrition, v.108, p.203-210, 1978.

HANNAH, S.S.; LAFLAMME, D.P. Effect of dietary protein on nitrogen balance and lean body mass in cats. Veterinary Clinical Nutrition, v.3, p.30, 1996.

HARPER, E.J. The energy requirements of senior dogs. Focus, v.7, p.32, 1997.

HARPER, E.J. Changing perspectives on aging and energy requirements: aging and energy intakes in humans, dogs and cats. Journal of Nutrition, v.128, p.2623S-2626S, 1998a.

HARPER, E.J. Changing perspectives on aging and energy requirements: aging, body weight and body composition in humans, dogs and cats. Journal of Nutrition, v.128, p.2627S2631S, 1998b.

HASLEWOOD, G.A. The biological significance of chemical differences in bile salts. Biology Review, v.39, p.537-574, 1964

HAYEK, M.G.; MASSIMINO, S.P.; BURR, J.R. et al. Dietary vitamin $\mathrm{E}$ improves immune function in cats. In: REINHART, G.A.; CAREY, D.P. (Eds.) Recent advances in canine and feline nutrition. 2000. p.555-564.

HAYES, K.C. Taurine nutrition. Nutrition Research Reviews, v.1, p.99-113, 1988.

HAZEWINKEL, H.A.W.; HOW, K.L.; BOSCH, R. et al. Inadequate photosynthesis of vitamin D in dogs. In: INTERNATIONAL SYMPOSIUM: Nutrition, Malnutrition and Dietetics in the Dog and Cat, 1987, Hanover, Germany. Proceedings... Hanover: British Veterinary Association, in collaboration with the Waltham Centre for Pet Nutrition, 1987.

HEAD, E. Combining an antioxidant fortified diet with behavioral enrichment leads to cognitive improvement and reduced brain pathology in aging canines: strategies for healthy aging. Annals of the New York Academy of Sciences, v.1114, p.398-406, 2007.

HEDHAMMAR, A.; WU, F.; KROOK, L. et al. Overnutrition and skeletal disease: an experimental study in growing Great Dane dogs. Cornell Veterinarian, v.64, p.11-160, 1974 (suppl $5)$.

HOUPT, K.A.; COREN, B.; HINTZ, H.F. et al. Effect of sex and reproductive status on sucrose preference, food intake and body weight of dogs. Journal of the American Veterinary Medical Association, v.174, p.1083-1085, 1979.

HOW, K.L.; HAZEWINKEL, H.A.W.; MOL, J.A. Dietary vitamin D dependence of cat and dog due to inadequate cutaneous synthesis of vitamin D. General Comparative Endocrinology, v.96, p.12-18, 1994.

IKEDA, M.H.; TSUJI, H.; NAKAMURA, S. et al. Studies on the biosynthesis of nicotinamide adenine dinucleotides. II. Role of picolinic carboxylase in the biosynthesis of NAD from tryptophan in mammals. Journal of Biological Chemistry 240, 1395-1401, 1965.

JACOB, F.; POLZIN, D.J.; OSBORNE, C.A. et al. Clinical evaluation of dietary modification for treatment of spontaneous chronic renal failure in dogs. Journal of the American Veterinary Medical Association, v.220, p.11631170, 2002.

KANCHUK, M.; BACKUS, R.C.; CALVERT, C.C. et al. Weight gain in gonadectomized normal and lipoprotein lipase-deficient male domestic cats results from increased food intake and not decreased energy expenditure. Journal of Nutrition, v.133, p.1866-1874, 2003.

KANE, E.; ROGERS, Q.R.; MORRIS, J.G. et al. Feeding behavior of the cat fed laboratory and commercial diets. Nutrition Research, v.1, p.499-507, 1981.

KEALY, R.D.; OLSSON, S.E.; MONTI, K.L. et al. Effects of limited food consumption on the incidence of hip dysplasia in growing dogs. Journal of the American Veterinary Medical Association, v.201, p.857-863, 1992.

KEALY, R.D. Factors influencing lean body mass in aging dogs. Compendium on Continuing Education for the Practicing Veterinarian, v.21, p.34-37, 1999.

KEALY, R.; LAWLER, D.; BALLAM, J. et al. Effects of diet restriction on life span and age-related changes in dogs. Journal of the American Veterinary Medical Association, v.220, n.9, p.1315-1320, 2002.

KEARNS, R.J.; HAYEK, M.G.; TUREK, J.J. et al. Effect of age, breed and dietary omega- $6(n-6)$ and omega-3 (n-3) fatty acid ratio on immune function, eicosanoid production, and lipid peroxidation in young and aged dogs. Veterinary Immunology and Immunopathology, v.69, p.165-183, 2000.

KIENZLE, E.; RAINBIRD, A. Maintenance energy requirement of dogs: What is the correct value for the calculation of metabolic body weight in dogs? Journal of Nutrition, v.121, p.S39S40, 1991.

LAFLAMME, D.P.; KEALY, R.D.; SCHMIDT, D.A. Estimation of body fat by body condition score. Journal of Veerinaryt Internal Medicine, v.8, p.154, 1994.

LAFLAMME, D.P. Nutrition for aging cats and dogs and the importance of body condition. Veterinary Clinics of North America: Small Animal Practice, v.35, p.713-742, 2005.

LAVELLE, R. The effect of overfeeding of a balanced complete diet to a group of growing great danes. In: BURGER, I.H.; RIVERS, J.P.W. (Eds.) Nutrition of the dog and cat Cambridge: Cambridge University Press, 1989. p.303-315.

LEWIS, L.D.; MORRIS JR., M.L.; HAND, M.S. Nutrients. In: Small Animal Clinical Nutrition III. Topeka: Mark Morris Associates, 1987a. p1-10.

LEWIS, L.D.; MORRIS JR., M.L.; HAND, M.S. Dogs - feeding and care. In: ___ Small Animal Clinical Nutrition III. Topeka: Mark Morris Associates, 1987b. p.3-32.

LINDE-FORSBERG, C. Abnormalities in canine pregnancy, parturition, and the periparturient period. In: ETTINGER, SJ.; FELDMAN, E.C. (Eds.) Textbook of veterinary internal medicine. St. Louis: Elsevier Saunders, 2010. p.1890-1901.

LLOYD, L.E.; MCCAY, C.M. The use of chromic oxide indigestibility and balance studies in dogs. Journal of Nutrition, 53:613-621, 1954.

LLOYD, L.E.; MCCAY, C.M. The utilization of nutrients by dogs of different ages. Journal of Gerontology, v.10, p.182-187, 1955.

LOVERIDGE, G.G. Bodyweight changes and energy intake of cats during gestation and lactation. Animal Technology, v.37, n.1, p.7-15, 1986.

LOVERIDGE, G.G.; RIVERS, J.P.W. Bodyweight changes and energy intakes of cats during pregnancy and lactation. In: BURGER, I.H.; RIVERS, J.P.W. (Eds.) Nutrition of the dog and cat Cambridge: Cambridge University Press, 1989. p.113-132. 
MARKHAM, R.W.; HODGKINS, E.M. Geriatric nutrition. Veterinary Clinics of North America: Small Animal Practice, v.19, p.165-185, 1989.

MARTIN, L.; SILIART, B.; DUMON, H. et al. Leptin, body fat content and energy expenditure in intact and gonadectomized adult cats: a preliminary study. Journal of Animal Physiology and Animal Nutrition, v.85, n.7-8, p.195-199, 2001.

MASSIMINO, S.; KEARNS, R.J.; LOOS, K.M. et al. Effects of age and dietary beta-carotene on immunological variables in dogs. Journal of Veterinary Internal Medicine, v.17, n.6, p.83542, 2003

MEYER, J.; STADTFELD, G. Investigation on the body and organ structure of dogs. In: ANDERSEN, R.S. (Ed.) Nutrition of the dog and cat. Oxford: Pergamon Press, 1980. p.15-30.

MORRIS, J.G.; TRUDELL, J.; PENCOVIC, T. Carbohydrate digestion by the domestic cat (Felis catus). British Journal of Nutrition, v.37, p.365-373, 1997.

MORRIS, J.G. Ineffective vitamin D synthesis in cats is reversed by an inhibitor of 7-dehydrocholosterol-7-reductase. Journal of Nutrition, v.129, p.903-908, 1999.

MORRIS, J.G. Idiosyncratic nutrient requirements of cats appear to be diet-induced evolutionary adaptations. Nutrition Research Reviews v.15, p.153-168, 2002.

MUNDAY, H.S.; EARLE, K.E. Energy requirements of the queen during lactation and kittens from birth to 12 weeks. Journal of Nutrition, v.121, p.S43-S44, 1991.

MUNDT, H.C. Nutrition of old dogs. Journal of Nutrition, v.121, p.S41-S42, 1991.

NATIONAL RESEARCH COUNCIL - NRC. Nutrient requirements of dogs and cats. Washington, D.C.: National Academies Press, 2006

NEILSON, J.C.; HART, B.L.; CLIFF, K.D. et al. Prevalence of behavioral changes associated with age-related cognitive impairment in dogs. Journal of the American Veterinary Medical Association v.218, p.1787-1791, 2001.

NGUYEN, P.G.; DUMON, H.J.; SILIART, B.S. et al. Effects of dietary fat and energy on body weight and composition after gonadectomy in cats. American Journal of Veterinary Research, v.65, p.1708-1713, 2004.

ONTKO, J.A.; PHILLIPS, P.H. Reproduction and lactation studies with bitches fed semipurified diets. Journal of Nutrition v.65, p.211-218, 1958.

PARK, T.; ROGERS, Q.R.; MORRIS, J.G. High dietary protein and taurine increase cysteine desulfhydration in kittens. Journal of Nutrition, v.129, p.2225-2230, 1999.

PEACHEY, S.E.; DAWSON, J.M.; HARPER, E.J. The effect of ageing on nutrient digestibility by cats fed beef tallow-, sunflower oil- or olive oil-enriched diets. Growth Development Aging, v.63, n.1-2, p.61-70, 1999.

PEREZ-CAMARGO, G. At nutrition: what's new in the old? Compendium on Continuing Education for the Practicing Veterinarian, v.26(suppl 2A), p.60, 2004.

PEREZ-CAMARGO, G. Feline decline in key physiological reserves implications for mortality. In: _- Companion animal nutrition summit, focus on gerontology. Clearwater Beach: 2010. p.5-11.
ROGERS, Q.R.; MORRIS, J.G.; FREEDLAND, R.A. Lack of hepatic enzymatic adaptation to low and high levels of dietary protein in the adult cat. Enzyme, v.22, p.348-356, 1977.

ROGERS, Q.R.; MORRIS, J.G. Why does the cat require a high protein diet? In: ANDERSON, R.S. (Ed.) Nutrition of the dog and cat. Oxford: Pergamon Press, 1980. p.45-66.

ROGERS Q.R.; PHANG, J.M. Deficiency of pyrroline-5-carboxylate synthase in the intestinal mucosa of the cat. Journal of Nutrition, v.115, p.146-150, 1985

ROMSOS, D.R.; PALMER, H.J.; MUIRURI, K.L. et al. Influence of a low carbohydrate diet on performance of pregnant and lactating dogs. Journal of Nutrition, v.111, p.678-689, 1981.

ROOT, M. Early spay-neuter in the cat. Veterinary Clinical Nutrition, v.2, p.132-134, 1995.

SCARLETT, J.M.; DONOGHUE, S. Associations between body condition and disease in cats. Journal of the American Veterinary Medical Association, v.212, n.11, p.1725-1731, 1988.

SHEFFY, B.E.; WILLIAMS, A.J.; ZIMMER, J.F. et al. Nutrition and metabolism of the geriatric dog. Cornell Veterinarian, v.75, p.324-347, 1985.

SPEAKMAN, J.R.; VAN ACKER, A.; HARPER, E.J. Age-related changes in the metabolism and body composition of three dog breeds and their relationship to life expectancy. Aging Cell, v.5, p.265-75, 2003.

SUDADOLNIK, R.J.; STEVENS, C.O.; DECHNER, R.H. et al. Species variation in the metabolism of 3-hydroxyanthranilate to pyridinecarboxylic acids. Journal of Biological Chemistry, 228, p.973-982, 1957.

TAYLOR, E.J.; ADAMS, C.; NEVILLE, R. Some nutritional aspects of aging in dogs and cats. Proceedings of the Nutritional Society, v.54, p.645-656, 1995.

THATCHER, C.D.; HAND, M.S.; REMILLARD, R.L. Small animal clinical nutrition: an iterative process. In: HAND, M.S.; THATCHER, C.D.; REMILLARD, R.L. et al. (Eds.) Small animal clinical nutrition. Topeka: Mark Morris Institute, 2010. p.3-21.

TURNER, R.G. Effect of prolonged feeding of raw carrots on vitamin A content of liver and kidneys of dogs. Proceedings of the Society for Experimental Biology, v.31, p.866-868, 1934.

WANNEMACHER, R.W.; MCCOY, J.R. Determination of optimal dietary protein requirements of young and old dogs. Journal of Nutrition, v.88, p.66-74, 1966.

WASHIZU, T.; TANAKA, A.; SAKO, T. et al. Comparison of the activities of enzymes related to glycolysis and gluconeogenesis in the liver of dogs and cats. Research in Veterinary Science, v.67, p.203-204, 1999

WICHERT, B.; SCHADE, L.; GEBERT, S. et al. Energy and protein needs of cats for maintenance, gestation and lactation. Journal of Feline Medicine and Surgery, v.11, p.808-815, 2009.

WILLS, J.M. Reproduction and lactation. In: KELLY, N.; WILLS, J. (Eds.) Manual of companion animal nutrition \& feeding. Ames: Iowa State University Press, 1996. p.47-51.

WILLS, J.M.; MORRIS, J.G. Feeding puppies and kittens. n: KELLY, N.; WILLS, J. (Eds.) Manual of companion animal nutrition \& feeding. Ames: Iowa State University Press, 1996. p.52-61. 